\title{
Review on Agricultural Extension Systems in Ethiopia: A Cluster Farming Approaches
}

\author{
Addisu Getahun $^{1^{*}} \quad$ Dawit Milkias $^{2}$ \\ 1.Ethiopian Institute of Agricultural Research (EIAR), Holeta Agricultural Research Center (HARC), P.O. Box: \\ 31, Holeta, Ethiopia \\ 2.Ethiopian Institute of Agricultural Research (EIAR), Ambo Agricultural Research Center (AARC), P.O. Box. \\ 37, Ambo, Ethiopia
}

\begin{abstract}
Ethiopia implemented several extensions approach to the agricultural sector since mid-1960s. This paper reviews the literatures on agricultural extension systems in Ethiopia and provides an overview of recent evidence on agricultural extension systems and explore the conceptual suggestion in technology dissemination and popularization. Farmer production clusters is a group of farmers who work together on shared interests and towards a common goal and these groups of farmers are required to adopt the latest full-package farm recommendations. The agricultural commercialization cluster initiative in Ethiopia across the four major agricultural regions of the country in Tigray, Amhara, Oromia and SNNPR is implemented with the aim of improving livelihoods, food quality and affordability, import substitution, export and agro-processing and creation of job opportunities. The observed data from ATA and CSA, 2019/20 in major crops on wheat, maize, barley, tef and sesame production in Tigray, Amhara, Oromia and SNNPR regions revealed that only $5.19 \%$ of farmers are part of farmers production cluster and $7.21 \%$ areas of land is cultivated through cluster farming. Hence, both governmental and non-governmental organization should focus on increasing the number participant farmers and areas to be allocated under cluster farming. In addition, emphasis should be given to the provisions of effective and efficient extension services with the full production package and on creating market linkages to improve farmers livelihoods through operation of cluster farming.
\end{abstract}

Keywords: Agricultural extension, agricultural technology, livelihoods, and cluster farming

DOI: $10.7176 / \mathrm{JBAH} / 11-14-01$

Publication date:July $31^{\text {st }} 2021$

\section{Introduction}

Ethiopia is the second most populous country in Africa next to Nigeria and ranked $12^{\text {th }}$ in the world, with an estimated population of 112,078,730 [1]. Ethiopia has a total land area of 1.1 million square kilometers and the country of great geographical diversity [2]. Ethiopia implemented several extensions approach to the agricultural sector since mid-1960s. The establishment of the land grant college at Haramaya (Alemaya college of Agriculture and Mechanical Arts), Agricultural technical schools (Ambo and Jimma) as well as area development projects such as ARDU, WADU and CADU, and the regular extension activities under the Ministry of Agriculture are the main developments in the history of agricultural extension in Ethiopia. During this time the focus was to improve living standards through increased production and infrastructure based its approach on agro-ecological zones [3].

Agricultural extension systems (AES) are defined as an agricultural information exchange system which shows the actors, people and institutions, their interactions and communication networks among these actors to coordinate the information related processes from generation to transfer, utilization and diffusion. As it was known the agricultural extension services assisted the agrarians to enhance agricultural production and productivity to meet the growing demand for food, industrial raw materials, and foreign currency earnings [4-5]. Agricultural technology adoption is a mental process through which an individual passes from hearing about an innovation to its adoption that follows awareness, interest, evaluation, trial, and adoption stages [6]. Agricultural research extension also used different approaches including FRG team, Demonstration fields (individual approach), Community based seed production (Farmers' cooperative/ group approach), Cluster based demonstration, Village based demonstration (integrated technology) and so on. The demand driven agricultural extension and advisory services have significant importance for agricultural development and rural livelihoods transformation.

Ethiopian ministry of agriculture through agricultural extension and communication directorate performs technology and knowledge dissemination, capacity building, and enhance the linkage and partnership with technology adopter/beneficiaries. The extension system is mandated to promote improved agricultural technologies and knowledge generated by the research system to the producer which contributes for food security. An acceptable and meaningful transformation of agricultural technologies through research extension system will be expected to improve productivity, build resilience to farming systems, improve livelihoods and reduce harm to the environment [7]. Even different extension systems implemented so far there is a gap on the 
level of technology adoption among farmers. Thus, the objective of this review paper is to assess the attributions of agricultural extension systems and cluster farming approaches on agricultural production and productivity.

\section{Literature Review}

\subsection{Basic concepts}

Agricultural technology: Agricultural technology refers the use of improved crop varieties, fertilizer, chemical inputs and agronomic practices in farming system [8].

Agricultural advisory services: Agricultural advisory services are defined as the entire set of organizations that support and facilitate people engaged in agricultural production to solve problems and to obtain information, skills, and technologies to improve their livelihoods and well-being [9].

Agricultural extension: Agricultural extension is defined as a transferring of information and technologies related to agriculture from the researchers to the farmers through the agricultural extension research in order to improve crop yields and farmers income. Improving the efficiency and effectiveness of the extension service provision through the rewarding and sanctions mechanisms at the grassroots level and familiarize with different actors can improve awareness about the change and enable farmers' access its benefits [10].

Agricultural Commercialization Clusters: It is defined as a shift from household production for homeconsumption to production for sale in the market. This shift entails that production and input use decisions are based on profit maximization, reinforcing vertical linkages between input and output markets [11]. In Ethiopia the concept of the Agricultural Commercialization Clusters (ACC) initiative was introduced during GTP I as a mechanism to integrate the interventions prioritized in the transformation agenda within specific geographies targeting a limited number of high-value commodities.

Farmer Production Clusters: It's a group of farmers who work to gather on shared interests and toward a common goal. Within the ACC, farm scale is achieved by clustering farmers in Farmer Production Clusters (FPC) project, where 30-200 farmers group together on adjacent land to farm as one. These groups of farmers (FPC farmers) are required to adopt the latest full-package farm recommendations, including use of improved seeds, fertilizer application, and other farming best-practices. Over time, it is expected that FPC farmers will move towards becoming established as commercial companies. Within the ACC, farm scale is achieved by clustering farmers in the Farmer Production Clusters (FPC) project, where 30-200 farmers group together on adjacent land to farm as one. These groups of farmers (FPC farmers) are required to adopt the latest full-package farm recommendations, including use of improved seeds, fertilizer application, and other farming best-practices [12].

\subsection{Agricultural Extension Progresses in Ethiopia}

Participatory Demonstration and Training Extension System: In 1995 the Government designed and implemented a Participatory Demonstration and Training Extension System (PADETES) as the core element of the extension system of the country. Its main objective was to improve participation of smallholder farmers and demonstrate improved agricultural technologies for improved productivity, incomes and livelihoods of the rural community [13]. The PADETES program has been an aggressive extension intervention that has involved 4.2 million participants from a total of about 10 million small-scale farmers in the country [14].

Agricultural technical and vocational education colleges: Agricultural technical and vocational education colleges provide trainees with the technical skills and practical knowledge applicable for agrarians. In 2000, the government invested in ATVET colleges to train DAs charged with carrying out agricultural extension activities with farm households.

Development agents: The government established and operationalized 25 ATVETs in different parts of the country to produce skilled development agents (DAs), sought to establish a Farmer Training Centre (FTC) in each kebele and deployed three DAs with specializations in crop, livestock and natural resources to each FTC. To-date over 70,000 DAs have been trained and graduated, of whom about 45,000 are currently deployed in agricultural extension [15]. DAs are the key source of appropriate information to farmers since they are working closely with farmers beside to their profession than other stakeholders in agriculture. For smooth extension service delivery DAs need means of transportation for reducing the time and transaction costs for field and farm visits. However, most DAs working under difficult conditions-lack of vehicles, lack of incentives, basic facilities in FTCs to provide trainings, minimum budget to conduct trainings, demonstrations and exhibitions [10].

Farmer training centers: In Ethiopia since 2002, more than 8,489 FTCs have been built at the kebele (the lowest administrative division) level. The centers are staffed by DAs and are responsible for providing extension activities in rural areas. Core activities concern livestock, crop production, and NRM. Measures to enhance the performance of the extension services include furnish adequately the FTCs to give services at full capacities and reuse of their internal revenue is one of the mechanisms to strength the capacity of FTCs rather fully depend on government budget allocation and encourage FTCs to generate their own income from demonstrations and crops in the land allocated for FTCs [10]. 


\subsection{The Cluster Farming Approaches}

The cluster approach to development aims to stimulate economic growth by increasing the benefits to farmers of being located in a certain geographical region. The agricultural commercialization clusters initiative contains clearly defined geographic clusters specializing in priority commodities across the four major agricultural regions of Ethiopia. These clusters are therefore are meant to serve as models for learning as Ethiopia intensifies the ACC approach and scales up best practices across the country. In parallel, many regions have begun to replicate the model across other geographies and commodities. The map below shows the location of the ACCs being implemented in 2011 and 2012 E.C.

The Agricultural Commercialization Clusters: the agricultural commercialization cluster was introduced to integrate efforts that benefit smallholder farmers as well as other value chain actors through a market-driven and geographically based approach. This allows better design and coordination of the interventions across public, private and development sector actors along the agricultural value chain, in order to enhance the impact on the ground and ensure gains are more sustainable. The ACC focuses on interventions that improve land productivity while reducing degradation, improve access to the domestic and international market, increase agro-processing and value-added activities, and create off-farm employment opportunities [12].

Through these interventions, the ACC program aims to commercialize smallholder agriculture through an inclusive and environmentally sustainable approach, improving incomes for the rural population while increasing youth employment and women's empowerment.

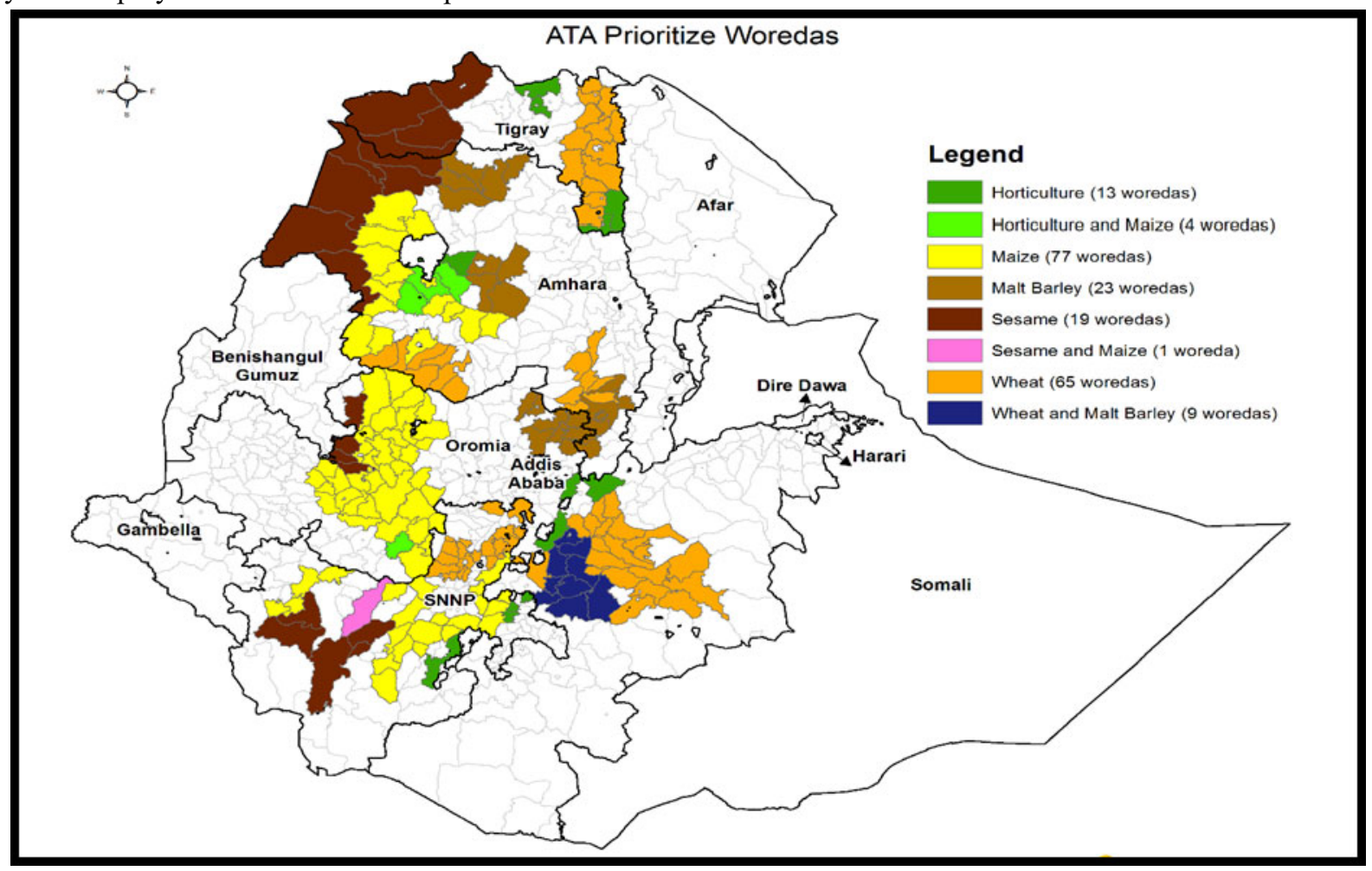

Figure 1. Location of the agricultural commercialization clusters

Source: Adopted from ATA, 2019/20

The ACC has five strategic objectives: Improved livelihoods: enable a sustainable increase in smallholder farmer productivity and profitability to increase income; Food quality and affordability: support quality output at an affordable price to domestic consumers; Import substitution: bridge gap between demand and supply by increasing production and marketable surplus; Export and agro-processing: increase the quality and amount supplied to agro-processing and export to raise foreign exchange; and Job opportunities: enable the agriculture sector to create meaningful jobs both on- and off-farm [12].

During the five-year period between 2019/20 and 2023/24, the ACC will focus on geographic clusters in the four major agricultural regions of Oromia, Amhara, SNNPR and Tigray and on ten priority commodities: five in grains crops (wheat, maize, malt-barley, sesame, tef) and five in horticultural crops (avocado, banana, mango, onion and tomato). Across the four regions, 300 selected woredas have been grouped into 31 crop clusters which enable agglomeration benefits to be realised in production, marketing, and value addition [12]. Tigray region farmer production clusters focused on wheat, sesame and tef in Tigray. In 2019/20 production year, 166,591 farmers are part of 3,956 FPCs in Tigray region and have cultivated over 51,103 hectares of land. 
Amhara region farmer production clusters focused on wheat, sesame, maize, malt barley and tef in Amhara region. In 2019/20 production year, over 384,200 farmers are part of 6,304 FPCs in Amhara and have cultivated over 155,142 hectares of land (Table 1).

Table 1. Farmer production clusters, areas, and number of farmers

\begin{tabular}{llrrr}
\hline \multirow{2}{*}{ Region } & \multicolumn{1}{c}{ Crop } & Number of Clusters & $\begin{array}{r}\text { Number of } \\
\text { FPC Farmers }\end{array}$ & Area of Land (hectares) \\
& Wheat & 2,509 & 101,444 & 26,699 \\
\multirow{2}{*}{ Tigray } & Tef & 1,074 & 53,006 & 11,795 \\
& Sesame & 373 & 12,141 & 12,609 \\
\hline \multirow{6}{*}{ Amhara } & Wheat & 1,972 & 132,922 & 50,821 \\
& Maize & 2,574 & 154,055 & 65,361 \\
& Malt barley & 433 & 28,016 & 4,240 \\
& Tef & 1,093 & 61,190 & 27,767 \\
& Sesame & 232 & 8,017 & 6,953 \\
\hline \multirow{5}{*}{ Oromia } & 4,125 & 140,691 & 60,256 \\
& Bread wheat & 1,798 & 49,353 & 28,816 \\
& Durum wheat & 6,829 & 256,368 & 106,793 \\
& Maize & 2,149 & 62,001 & 27,846 \\
& Malt barley & 2,784 & 81,038 & 29,700 \\
& Tef & 37 & 508 & 659 \\
\hline \multirow{2}{*}{ SNNPame } & 1,216 & 91,251 & 37,936 \\
& Wheat & 38 & 5,848 & 20,856 \\
& Sesame & 1,208 & 242,695 & 48,707 \\
& Maize & 9,651 & 13,793 \\
\hline
\end{tabular}

Source: Agricultural Transformation Agency (ATA), 2019/20

Oromia region farmer production clusters focused on wheat, sesame, maize, malt barley and tef in Oromia. In 2019/20 production year, more than 589,959 farmers are part of 17,722 FPCs in Oromia region and have cultivated over 254,070 hectares of land. SNNP region farmer production clusters focused on wheat, sesame, maize and tef in SNNP. In 2019/20 production year, over 179,445 farmers are part of 2,706 FPCs in SNNP region and have cultivated more than 121,292 hectares of land [12] (Table 1).

Agriculture in Ethiopia is at subsistence and the major food crops are produced in almost all regions of the country in spite of the variation in volume of production across the regions. The variation may be attributed to the extent of area devoted to each crop type, weather change and a shift in preference for the crops grown. The results of the year 2019/20 (2012 E.C.), Meher season post-harvest crop production survey has been summarized and quantitative information with regard cropped land area, number of farmers and production of some crops are shown below at regional levels [16]. As shown on Table 2 below in 2019/20 production year 25,429,914 farmers cultivated 8,063,885 hectares of land and produced 222,879,070 quintals (Table 2).

Table 2. Number of holders, area and production of major crops

\begin{tabular}{clccc}
\hline Region & \multicolumn{1}{c}{ Crop } & Number of Holders & Area in Hectares & Production in Quintals \\
\hline \multirow{3}{*}{ Tigray } & Wheat & 386,778 & 102,258 & $2,239,072$ \\
& Teff & 633,525 & 188,392 & $3,117,539$ \\
& Sesame & 145,151 & 108,291 & 811,043 \\
\hline \multirow{5}{*}{ Amhara } & Wheat & $1,932,885$ & 578,034 & $16,117,841$ \\
& Maize & $2,979,969$ & 532,483 & $22,751,208$ \\
& Barley & $1,196,450$ & 321,515 & $7,512,997$ \\
& Teff & $2,659,496$ & $1,156,131$ & $21,892,366$ \\
& Sesame & 239,756 & 200,253 & $1,360,998$ \\
\hline \multirow{5}{*}{ Oromia } & Wheat & $1,831,185$ & 970,518 & $30,933,982$ \\
& Maize & $5,095,180$ & $1,207,526$ & $53,217,963$ \\
& Barley & $1,480,942$ & 458,574 & $12,649,705$ \\
& Teff & $2,742,049$ & $1,487,971$ & $28,090,978$ \\
& Sesame & 89,168 & 36,492 & 247,134 \\
\hline \multirow{2}{*}{ SNNP } & Wheat & 715,807 & 134,475 & $3,765,613$ \\
& Maize & $2,223,614$ & 339,963 & $14,366,428$ \\
& Teff & $1,077,959$ & 241,009 & $3,804,203$ \\
\hline
\end{tabular}

Source: Central Statistical Agency (CSA), 2020

As revealed from Table 1 and Table 2 above on the data of major crop wheat, maize, barley, tef and sesame production on the four major agricultural regions of the country in Tigray, Amhara, Oromia and SNNPR only 
5.19 percent of farmers participated under farmers production cluster and the areas of land cultivated through cluster farming is only 7.21 percent. Therefore, it's expected to expected the coverage of the approaches both in number of holders and areas of production. Ethiopia's labor-intensive subsistence farming coupled with rain fed agricultural system remained unproductive for centuries, which needs to transform the archaic approach into modern one. In Ethiopia since recent years, cluster farming development have helped small-scale farmers to increase the productivity of wheat, maize, tef, barley and other type food of crops on the top of boosting food security.

The introduction of cluster farming approach to development aims to stimulate economic growth by increasing harvest and boost food security benefits farmers located in a certain geographic region. With the cluster farming development program, small-scale farmers in the various regions have a progress to extensively increase their agricultural productivity and value chain products, which in turn helped them to build up food security. The agricultural commercialization initiative was developed as an approach to integrate geographically targeted interventions to insure rapid, sustainable and inclusive development for prioritized agricultural commodity value chains.

Smallholder farmers who take part in cluster farming are provided supports that range from training and advisory service to facilitation on introductions of new technologies, input supply, and market linkages. Cluster farming is practically important and effective in employing mechanization technologies and the prevention of post-harvest losses. Farmers under cluster farming can rent tractors, combiners, agrochemical spry machine in a group as they prepare their lands, take care of weeds and pests, as well as harvest crops at similar times. This also gives a cost minimization due to economies of scale in both input and output markets.

\section{Conclusion and Recommendation}

Ethiopia is the second most populous country in Africa next to Nigeria and ranked $12^{\text {th }}$ in the world, with an estimated population of 112,078,730 and Ethiopia has a total area of 1.1 million square kilometers and the country of great geographical diversity. Agricultural technical and vocational education colleges provide trainees with the technical skills and practical knowledge applicable for agrarians. Development agents are the key source of appropriate information to farmers since they are working closely with farmers beside to their profession than other stakeholders in agriculture. Farmer training centers are responsible for providing extension activities in rural areas with the concern on the crop production, livestock, and natural resource management sectors.

Farmer production clusters is a group of farmers who work to gather on shared interests and toward a common goal and these groups of farmers are required to adopt the latest full-package farm recommendations, including use of improved seeds, fertilizer application, and other farming best-practices. The agricultural commercialization cluster initiative in Ethiopia contains clearly defined geographic clusters specializing in priority commodities across the four major agricultural regions of the country in Tigray, Amhara, Oromia and SNNPR.

The agricultural commercialization cluster is implemented with the strategic objectives of improving livelihoods, food quality and affordability, import substitution, export and agro-processing and creation of job opportunities. Hence, the interaction and collaboration various actors and institutions play important roles in Ethiopia's extension system for delivery of effective and efficient extension services. Attention should be given on increasing the number farmers under cluster farming and the areas of land to be allocated for cluster farming and the provisions of advisory services with the full production package and creating market linkages in cluster farming for agricultural development and farmers livelihoods improvement.

\section{References}

Bahadur, K.L. and B. Siegfried (2004), Technology Adoption and Household Food Security. Analyzing Factors Determining Technology Adoption and Impact of Project Intervention: A Case of Smallholder Peasants in Nepal, Paper prepared for presentation at the Deutscher Tropentag, 5-7 October 2004, Humboldt University, Berlin.

Bahadur, K.L. and B. Siegfried (2004), Technology Adoption and Household Food Security. Analyzing Factors Determining Technology Adoption and Impact of Project Intervention: A Case of Smallholder Peasants in Nepal, Paper prepared for presentation at the Deutscher Tropentag, 5-7 October 2004, Humboldt University, Berlin.

[1] World Population Prospects. 2019. The 2019 Revision of World Population Prospects: United Nations Population Division. p.2.

[2] IFPRI/ CSA. 2006. Atlas of the Ethiopian Rural Economy (advance copy). International Food Policy Research Institute, Washington, DC, USA, and the Central Statistical Agency, Addis Ababa, Ethiopia.

[3] Abate, H. 2007. Review of extension systems applied in Ethiopia with special emphasis to the participatory demonstration and training extension system. Rome: Food and Agriculture Organization of the United 


\section{Nations.}

[4] MoANR. 2017. Ethiopia's agricultural extension strategy: Vision, systemic bottleneck and priority intervention. Ministry of Agriculture and Natural Resources, Addis Ababa, Ethiopia.

[5] Gerba L, Girma K, Stellmacher T, and Hornidge A. 2017. The agricultural extension system in Ethiopia: operational setup, challenges and opportunities ZEF Working Paper 158 Series, ISSN 1864-6638.

[6] Bahadur, K.L. and B. Siegfried. 2004. Technology Adoption and Household Food Security. Analyzing Factors Determining Technology Adoption and Impact of Project Intervention: A Case of Smallholder Peasants in Nepal, Paper prepared for presentation at the Deutscher Tropentag, 5-7 October 2004, Humboldt University, Berlin.

[7] Nyasimi M, Amwata D, Hove L, Kinyangi J, and Wamukoya G. 2014. Evidence of impact: climate-smart agriculture in Africa. In: CCAFS working paper no. 86.

[8] Evenson, R.E. and Gollin, D. 2003. Assessing the Impact of the Green Revolution, 1960 to 2000. Science, 300, 758-762. http://dx.doi.org/10.1126/science.1078710

[9] Birner R., K. E. Davis, J. Pender, E. Nkonya, P. Anandajayasekeram, J. Ekboir, A. Mbabu, D. J. Spielman, D. Horna, S. Benin, and M. Cohen 2009. "From Best Practice to Best Fit: A Framework for Designing and Analyzing Pluralistic Agricultural Advisory Services Worldwide. Journal of Agricultural Education and Extension 15 (4): 341-355.

[10] Mekonnen Hailu, Degefa Tolossa, Belay Kassa, and Anteneh Girma. 2020. Understanding Factors Affecting the Performance of Agricultural Extension System in Ethiopia. Ethiop. J. Agric. Sci. 30(4) 237263. Addis Ababa, Ethiopia.

[11] Olwande, J., Smale, M., Mathenge, M. K., Place, F. and Mithofer, D. 2015. Agricultural marketing by smallholders in Kenya: A comparison of maize, kale and dairy. Food Policy, 52(2015): 22-32.

[12] Agricultural Transformation Agency. 2019/20. http://www.ata.gov.et/our-approach/agriculturalcommercialization-clusters-2/.

[13] EEA (Ethiopian Economic Association) / EEPRI (Ethiopian Economic Policy Research Institute). 2006. Evaluation of the Ethiopian agricultural extension with particular emphasis on the Participatory Demonstration and Training Extension System (PADETES). Addis Ababa, Ethiopia.

[14] Kelemework, F., and H. Kassa 2006. Assessment of the current extension system of Ethiopia: A closer look at planning and implementation. Issue Paper 2/2006. Addis Ababa, Ethiopia: Ethiopian Economic Association / Ethiopian Economic Policy Research Institute.

[15] Lemma, T., Sehai, E. and Hoekstra, D. 2010. Status and capacity of FTCs in Improving productivity and Market Success Pilot Learning Woredas. ILRI, Addis Ababa.

[16] CSA (Central Statistical Agency). 2020. Agricultural Sample Survey 2019/2020 (2012 E.C): Report on area and production of major crops, volume-I. Addis Ababa, Ethiopia. 